\title{
Minimizing Mother Bulb Requirement through Mechanical Option: A Cost Friendly Approach of Onion Seed Production
}

\author{
D.K. Ghosh ${ }^{1}$, L.K.N. Benukar Biswas ${ }^{2}$, S. Das ${ }^{1}$, C.S. Kartick $^{1}$ and A. Bandyopadhyay ${ }^{1}$ \\ ${ }^{1}$ Department of Spices and Plantation Crops, ${ }^{2}$ Department of Agronomy, Bidhan Chandra \\ Krishi Viswavidyalaya, Mohanpur, West Bengal, India 741252 \\ *Corresponding author
}

\begin{abstract}
A B S T R A C T
Reduction of seed production cost of onion in India may play an important role in bridging the demand-supply gap of onion bulb in both domestic as well as international market, but choices to be made require appropriate cultural manipulations to reduce the mother bulb requirement, the key cost component of seed production. A field experiment in West Bengal, India was conducted between 2014-15 to 2016-17 on a clay loam (Alfisol) soil to evaluate seed production using five different portions of mother bulb (whole bulb of 70$80 \mathrm{~g}$; cross section cut at middle of $40-50 \mathrm{~g}$; longitudinally half cut of $35-40 \mathrm{~g}$; longitudinally one third cut of 30-35 g and small but whole bulb of 30-35g) of Sukhsagar variety. Growth, productivity, production cost and net return generally increased with increasing mother bulb size. However, umbels per plant, seeds per umbel, setting percentage, test weight, seed yield and gross return were at par with using whole bulb of $70-80 \mathrm{~g}$ and longitudinally half cut of 35-40 g. Cost analysis of onion seed production shows $70.86 \%$ share alone in procuring mother bulb. Thus, longitudinally half cut reduced mother bulb requirement by $50 \%$. Net return, benefit cost ratio, benefit in terms of rupees or grams per unit rupee investment in mother bulb were higher than that of using whole mother bulb. Based on economic considerations alone, half cut bulb of 35-40 g weight can be recommended instead of using conventional whole bulb of 70-80g weight as cost saving onion seed production options with a possibility of doubling area.
\end{abstract}

\section{Keywords}

Onion bulb size, Longitudinal cut, Umbel,

Productivity, Profitability

Article Info

Accepted:

20 June 2018

Available Online:

10 July 2018

\section{Introduction}

Onion is one of the important bulbous crops in India earning foreign currency through export. India is the second largest producers of onion (Allium cepa L.) in the world next to China with $20 \mathrm{~m} \mathrm{t}$ annual bulb production from 1.17 $\mathrm{m}$ ha (2015-16). The average productivity $\left(17.32 \mathrm{tha}^{-1}\right)$ is very low as compared to USA $\left(41.12 \mathrm{t} \mathrm{ha}^{-1}\right)$. This is mainly because of the growing of short day varieties in large scale along with the limited availability of quality seeds. Farmers, in India, are producing more than $90 \%$ seeds from their own sources. Size and weight of the bulb is one of the most important factors affecting onion seed production (Khodadadi, 2012; Asduzzaman et al., 2012). Higher is the size and weight of 
bulb, higher is the seed yield in onion (Ranjan et al., 2016; Singh and Singh; 2012 and Agarwal et al., 2010). There are some studies on effect of planting date and mulching (Anisuzzaman et al., 2009), of mineral nutrition (Ali et al., 2007), of enzyme (De et al., 2013), of organics (Naik et al., 2014) on onion. Though the main cost component of onion seed production is the mother bulb but most of the previous works have focused on specific said aspects of onion seed production. Studies providing an option to reduce the mother bulb requirement through mechanical manipulation have remained relatively rare in the scientific literature, but they are needed for understanding options for reducing production cost vis-a-vis horizontal expansion of onion area in India. Here we present an effect of five different portions of mother bulb (whole bulb of 70-80g; cross section cut at middle of 40$50 \mathrm{~g}$; longitudinally half cut of $35-40 \mathrm{~g}$; longitudinally one third cut of 30-35 g and small but whole bulb of 30-35g) of Sukhsagar variety on growth, productivity and profitability.

\section{Materials and Methods}

A field experiment for 3 years was conducted between 2014 to 2017 at the farm of the Bidhan Chandra Krishi Viswavidyalaya, Kalyani, Nadia, West Bengal, India, located in the Gangetic flood plain of the Eastern IGP (Lat. $23.5^{0} \mathrm{~N}$, Long. $89^{0} \mathrm{E}$, Elev. $9.75 \mathrm{~m}$ a.s.1.). Prior to the experiment, the field had been under irrigated rice-onion cropping for 5 years. The soil of the experimental field is a very deep, well-drained, clay loam with $44 \%$ sand, $28 \%$ silt and $28 \%$ clay in the surface layer $(0-15 \mathrm{~cm})$. Initial properties of a composite soil sample collected at the beginning of the field experiment where $4.9 \mathrm{~g}$ $\mathrm{kg}^{-1}$ organic carbon (Walkley-Black), $0.48 \mathrm{~g}$ $\mathrm{kg}^{-1}$ total $\mathrm{N}$ (Kjeldahl), $44 \mathrm{~kg} \mathrm{ha}^{-1}$ available $\mathrm{P}$ (Bray-1), $149 \mathrm{~kg} \mathrm{ha}^{-1}$ available K (1N NH4acetate), and a $\mathrm{pH}$ of 6.9 (1:2.5 soil: water) were recorded. Weather during crop season (November to April) was almost stable during the period of experimentation except temperature (Fig. 1). Higher temperature was recorded during 2015-16. Average annual rainfall at this place over last 3 years is 1582 $\mathrm{mm}$. Mean monthly temperature over the experimental period ranges from $9.3^{\circ} \mathrm{C}$ (minimum) in February to $39.0^{\circ} \mathrm{C}$ (maximum) in May. Mean daily maximum and minimum relative humidity over the period was $60 \%$ and $93 \%$, respectively.

The experiment was laid out in a randomized complete block design with $9 \mathrm{~m}$ X 6 m plots replicated four times. Five different portions of mother bulb (whole bulb of $70-80 \mathrm{~g}-\mathrm{T}_{1}$; cross section cut at middle of $40-50 \mathrm{~g}-\mathrm{T}_{2}$; longitudinally half cut of $35-40 \quad \mathrm{~g}-\mathrm{T}_{3}$; longitudinally one third cut of 30-35 g- $\mathrm{T}_{4}$ and small but whole bulb of $30-35 \mathrm{~g}-\mathrm{T}_{5}$ ) of Sukhsagar variety were used as propagating material (Fig. 2).

The field was ploughed thoroughly by tractor to a fine tilth by giving four ploughings followed by leveling. The field was then divided into beds and channels to avoid water logging which affects production and quality of seeds. 25 tones of FYM ha ${ }^{-1}$ were applied at the time of land preparation. Recommended dose of fertilizers (125: 60: $90 @ \mathrm{~N}: \mathrm{P}_{2} \mathrm{O}_{5}$ : $\mathrm{K}_{2} \mathrm{O} \mathrm{kg} \mathrm{ha}{ }^{-1}$ ) were applied in two split doses. $1 / 2 \mathrm{~N}$, full $\mathrm{P}_{2} \mathrm{O}$, and $1 / 2 \mathrm{~K}_{2} \mathrm{O}$ as basal and rest at 25 days after planting as top dressing and earthing up was followed after topdressing. Treated mother bulbs were planted within first fortnight of November. Need based irrigation and eco friendly plant protection measures were taken. Diseased and off-type plants were rouged out before flowering for quality seed production. Five plants from each plot were selected for recording of spikes per plant, spike length, basal diameter of spike, umbel diameter, setting \%, test weight and seed yield. Prices of individual inputs and outputs 
(diesel@Rs 63.25 per liter, labor@ @s 170 per 8-h day, mother bulb @ Rs 40000 per ton, Urea@Rs.6.5 per kg, MOP @ Rs 12 per kg, SSP @ Rs 8 per kg, Imida-chloroprid@Rs 1400 per liter, Propiconazole @ Rs 800 per liter) were assumed to be stable during the experimental period. Family labor at the mean wage rate of hired labor was included in the cost calculations, thus ignoring possible opportunity costs. Treatment wise detailed production costs were shown in Table 1. Net return or profit was calculated by subtracting production cost from the gross value of the produce. Prices used for harvest products were average prices observed during the experimental period. The benefit: cost ratio (BCR) was calculated by dividing the net return by the production cost. Statistical analysis for each variable was conducted as per the procedure given by Gomez and Gomez (1984). Wherever the results were significant, least significant differences (LSD) were worked out at probability level $\mathrm{p} \leq 0.05$ using the ANOVA. The non-significant treatment differences were denoted as NS.

\section{Results and Discussion}

\section{Growth and yield component}

Mother bulb size as well as type of cutting of bulbs influenced the growth and development of onion. Higher is the size better is the performance. Among the cutting pattern, half longitudinal cut outperformed cross section at middle or one third longitudinal cuttings in terms of spikes per plant, basal diameter of the spike, umbel diameter, seeds per umbel, setting percentage and test weight. It is also observed that half longitudinal cut bulb of 35$40 \mathrm{~g}$ weight was at par with planting whole bulb of standard size of 70-80 $\mathrm{g}$ weight in terms of growth parameters evaluated. The pooled data over three years (2014-15 to 2016-17) presented in Table-3 reveals that maximum number of spikes plant ${ }^{-1}$ (4.92) were recorded under treatment $\mathrm{T}_{1}$ followed by $\mathrm{T}_{3}$ (4.7) which are at par with each other. Treatment $\mathrm{T}_{4}$ recorded lowest number of spikes plant ${ }^{-1}(2.6)$. Regarding spike length, maximum spike length of $94 \mathrm{~cm}$ was recorded under treatment $T_{3}$ followed by $T_{1}$ and $T_{2}$ which are at par with each of three. $\mathrm{T}_{5}$ (e.g. small whole bulb, wt.30-35g) recorded minimum spike length of $75 \mathrm{~cm}$. Basal diameter of spike was recorded maximum $(7.69 \mathrm{~cm})$ under treatment $\mathrm{T}_{1}$ and minimum $(6.14 \mathrm{~cm})$ was recorded in treatment $T_{4}$. Treatment wise seeds per umbel were recorded maximum under treatment $\mathrm{T}_{1}$ (593 numbers) followed by $\mathrm{T}_{3}$ (578 numbers) which are at par with each other. Seed setting $\%$ per umbel was also recorded maximum (73\%) in treatment $\mathrm{T}_{1}$ followed by $\mathrm{T}_{3}(71 \%)$ and lowest in $\mathrm{T}_{5}$ (54\%). Test seed weight was also recorded highest $(3.42 \mathrm{~g})$ in treatment $T_{1}$ followed by $\mathrm{T}_{3}(3.4 \mathrm{~g})$ which are at par with each other and lowest seed weight was recorded by $\mathrm{T}_{5}(2.81 \mathrm{~g})$.

\section{Productivity}

Onion seed yield was also in agreement with the growth performance. Equivalent seed production was observed between using standard whole bulb (70-80g) and its longitudinal $1 / 2$ cutted bulb. Year wise onion seed production was maximum in 2014-15 $\left(0.571 \mathrm{t} \mathrm{ha}^{-1}\right)$, followed by 2016-17 (0.481 t $\left.\mathrm{ha}^{-1}\right)$, and lowest seed yield was recorded in the year 2015-16 (0.435 $\left.\mathrm{t} \mathrm{ha}^{-1}\right)$, (Table 4). From the year wise mean data presented in Table 4 it is revealed that $T_{1}$ recorded maximum seed yield of $0.732 \mathrm{tha}^{-1}$ followed by $\mathrm{T}_{3}\left(0.696 \mathrm{t} \mathrm{ha}^{-1}\right)$ and the most interesting fact is that both the treatments are statistically at par with each other. Treatment $\mathrm{T}_{4}$ recorded minimum seed yield of $0.285 \mathrm{t} \mathrm{ha}{ }^{-1}$. Temperature at reproductive stage is one of the most important factors for onion seed production. From the weather data, it was observed that in 2014-15 during reproductive 
stage maximum temperature was up to $18.7^{\circ} \mathrm{C}$ whereas it was up to $25.6^{\circ} \mathrm{C}$ during $2015-16$ (Fig. 1) and this variation in terminal heat condition greatly influenced the seed development and production. Olani Nikus and Fikre Mulugeta (2010) and Khokhar (2014) had reported that temperature ranges between $4.5-14^{\circ} \mathrm{C}$ with low humidity is favorable for seed stalk formation. If this type of temperature prevails for longer periods then each plant will produce more number of flowers in each umbel. Higher temperature prevails long time during flowering season can prevent flowering followed by flower abortion resulted in low seed yield and this was clearly reflected in the year 2015-16 where temperature range was maximum (14.8$25.6^{0} \mathrm{C}$ ) in comparison with the years 2014-15 and 2016-17 and as a result over all vegetative growth of the plants, seed setting percentage, and seed yield were minimum in 2015-16 irrespective of any treatments. Yield components and productivity in $\mathrm{T}_{1}$ and $\mathrm{T}_{3}$ was equivalent. More number of spikes plant ${ }^{-1}$ and seed yield recorded in treatment $T_{3}$, may be due to the removal of dominancy of the apical buds by imposing longitudinal cut which allows auxiliary buds or side buds with better growth and development of more spike and ultimately better seed yield. Thimann and Skoog (1934) reported that apical bud produces the plant hormone auxin (IAA) which regulates apical dominance by inhibiting the growth of the lateral buds further down on the stem towards the axillary bud. The imposition of inhibition of auxin mediated apical dominancy on main bud with longitudinal cut in mother bulb may promote cytokine mediated initiation of more lateral buds.

Booker et al., (2003) reported that auxin is predominantly produced in the growing shoot apex and diffuses into lateral buds through phloem and prevents elongation. Physiologically, in onion the stem is shortened down to a disc which is often called the basal plate or reduced stem (Fig. 2 and 3). The leaf bases are attached to the upper surface of the reduced stem and roots arise around the edge. The auxiliary buds or side buds always developed at the node where the leaves attach and in the center there will be one apical bud or main bud which can grow first due to its better vigor and apical dominancy over auxiliary or side buds. This observation confirms the findings of Razdan (2003) where he had mentioned that the development of auxiliary meristems is inhibited by apical dominance. Burrows (1989) reported that those auxiliary meristems are commonly the source of buds formation in nature especially when the apical shoots are damaged or injured. Singh et al., (2011) recorded that in banana macro and micro propagation decapitation and wounding of shoot tips overcome the apical dominance and encourage auxiliary bud proliferation. Hussein (2012) also reported that longitudinally bud splitting technique in banana during tissue culture process increases the number of explants. This is thought to promote buds proliferation by breaking the apical dominance (Wooley and Wareing, 1972).

\section{Economics:}

From the figure 3, it is clear that the mother bulb is the key cost component of onion seed production contributing $70.86 \%$ alone followed by labor (18.52\%). Availability as well as purchasing capacity of this costly propagating material actually controls the area coverage of this crop. Here, different portions and/or sizes of mother bulb were tried to reduce bulb requirement for horizontal expansion without compromising vertical stability. Treatment wise percentage of cost involved in mother bulb varies from 44 to 69 $\%$ in comparison to $71 \%$ in conventional (Fig. 3 ). So, seed material cost may be reduced with this mechanical manipulation. 
Table.1 Input requirement of onion seed production with different size \&/or portion of mother bulb in a field experiment in West Bengal, India

\begin{tabular}{|l|r|r|r|r|r|}
\hline Item & \multicolumn{5}{|c|}{ Treatment wise Input requirement } \\
\hline Diesel $\left(\right.$ l ha $\left.^{-1}\right)$ & $\mathrm{T} 1$ & $\mathrm{~T} 2$ & $\mathrm{~T} 3$ & $\mathrm{~T} 4$ & T5 \\
\hline Labor $\left(8-\mathrm{h} \mathrm{days} \mathrm{ha}^{-1}\right)$ & 82.5 & 82.5 & 82.5 & 82.5 & 82.5 \\
\hline Mother Bulb (t ha-1) & 369 & 429 & 444 & 399 & 309 \\
\hline FYM (t ha-1) & 6 & 6 & 3 & 2 & 3 \\
\hline Fertilizer N (kg ha-1) & 25 & 25 & 25 & 25 & 25 \\
\hline Fertilizer P2O5 (kg ha-1) & 125 & 125 & 125 & 125 & 125 \\
\hline Fertilizer K2O (kg ha-1) & 60 & 60 & 60 & 60 & 60 \\
\hline Imida-chloroprid 17.8 sl(1 ha-1) & 90 & 90 & 90 & 90 & 90 \\
\hline Propiconazole25\% EC(1 ha-1) & 0.9 & 0.9 & 0.9 & 0.9 & 0.9 \\
\hline T. & 2.7 & 2.7 & 2.7 & 2.7 & 2.7 \\
\hline
\end{tabular}

$\mathrm{T}_{1}$ : Whole bulb (70-80 g); $\mathrm{T}_{2}$ : Cross section cut at middle (40-50g); $\mathrm{T}_{3}$ : Longitude cut (half) (35-40 g); $\mathrm{T}_{4}$ : Longitude cut (one third) (30-35 g); $\mathrm{T}_{5}$ : Small but whole bulb (30-35 g)

Table.2 Production cost ( $\mathrm{Rs} \mathrm{ha}^{-1}$ ) of onion seed production with different size \&/or portion of mother bulb in a field experiment in West Bengal, India

\begin{tabular}{|l|c|c|c|c|c|}
\hline Item & \multicolumn{5}{|c|}{ Treatment wise production cost (Rs ha-1) } \\
\hline & T1 & T2 & T3 & T4 & T5 \\
\hline Diesel & 5218 & 5218 & 5218 & 5218 & 5218 \\
\hline Labor & 62730 & 72930 & 75480 & 67830 & 52530 \\
\hline Mother Bulb & 240000 & 240000 & 120000 & 80000 & 120000 \\
\hline FYM & 20000 & 20000 & 20000 & 20000 & 20000 \\
\hline Fertilizer N & 1766 & 1766 & 1766 & 1766 & 1766 \\
\hline Fertilizer P2O5 & 3000 & 3000 & 3000 & 3000 & 3000 \\
\hline Fertilizer K2O & 1800 & 1800 & 1800 & 1800 & 1800 \\
\hline Imida-chloroprid & 1260 & 1260 & 1260 & 1260 & 1260 \\
\hline Propiconazole25\% EC & 2160 & 2160 & 2160 & 2160 & 2160 \\
\hline Depreciation & 613 & 613 & 613 & 613 & 613 \\
\hline Tax & 147 & 147 & 147 & 147 & 147 \\
\hline Total & 338694 & 348894 & 231444 & 183794 & 208494 \\
\hline
\end{tabular}

$\mathrm{T}_{1}$ : Whole bulb (70-80 g); $\mathrm{T}_{2}$ : Cross section cut at middle (40-50g); $\mathrm{T}_{3}$ : Longitude cut (half) (35-40 g); $\mathrm{T}_{4}$ : Longitude cut (one third) (30-35 g); $\mathrm{T}_{5}$ : Small but whole bulb (30-35 g)

Table.5 Effect of mother bulb portion on economics of onion seed production

\begin{tabular}{|c|c|c|c|c|}
\hline Mother bulb portion & $\begin{array}{c}\text { Production cost } \\
\text { (Rs ha }^{-1} \text { ) }\end{array}$ & $\begin{array}{c}\text { Gross return } \\
\text { (Rs ha }^{-1} \text { ) }\end{array}$ & $\begin{array}{c}\text { Net return }(\mathrm{Rs} \\
\left.\text { ha }^{-1}\right)\end{array}$ & B:C ratio \\
\hline $\mathbf{T}_{\mathbf{1}}$ & 338694 & 878400 & 539706 & 1.59 \\
\hline $\mathbf{T}_{\mathbf{2}}$ & 348894 & 520800 & 171906 & 0.49 \\
\hline $\mathbf{T}_{\mathbf{3}}$ & 231444 & 835200 & 603756 & 2.61 \\
\hline $\mathbf{T}_{\mathbf{4}}$ & 183794 & 342000 & 158206 & 0.86 \\
\hline $\mathbf{T}_{\mathbf{5}}$ & 208494 & 397200 & 188706 & 0.91 \\
\hline $\mathbf{L S D}(\mathbf{0 . 0 5})$ & 40463 & 90144 & & 0.24 \\
\hline
\end{tabular}

$\mathrm{T}_{1}$ : Whole bulb (70-80 g); $\mathrm{T}_{2}$ : Cross section cut at middle $(40-50 \mathrm{~g}) ; \mathrm{T}_{3}$ : Longitude cut (half) (35-40 g); $\mathrm{T}_{4}$ : Longitude cut (one third) (30-35 g); $\mathrm{T}_{5}$ : Small but whole bulb (30-35 g) 


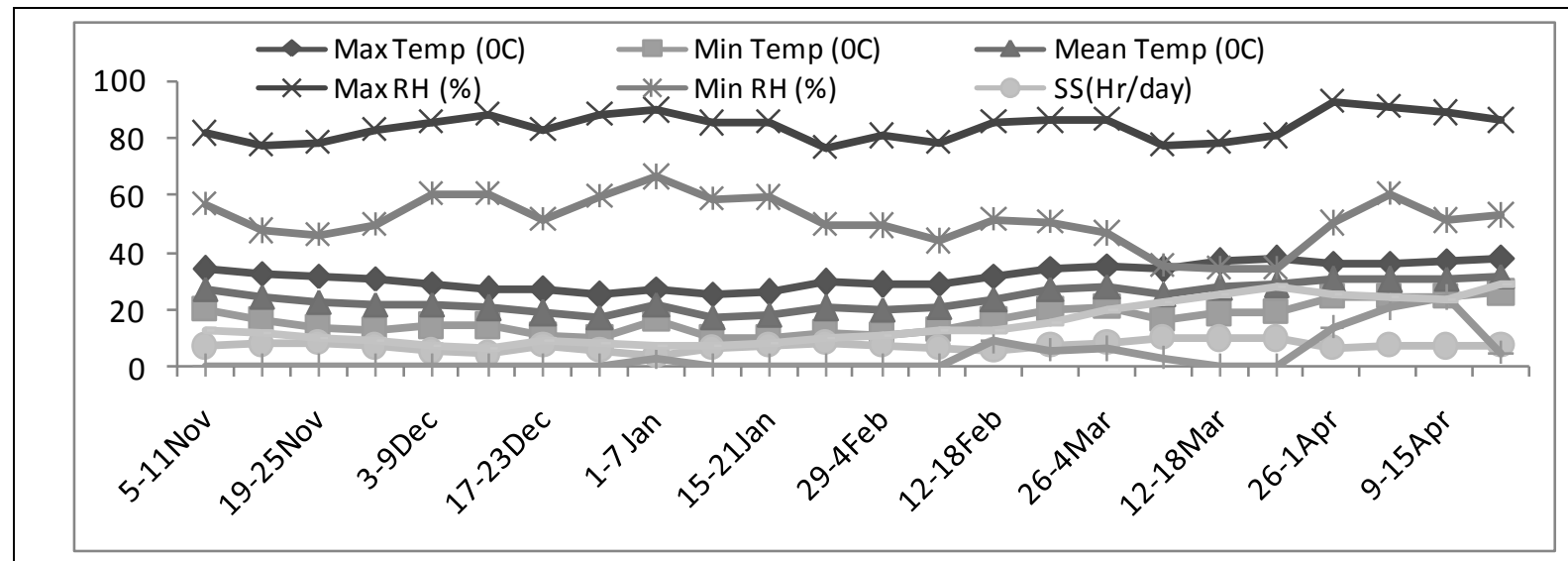

Standard week (2014-2015)

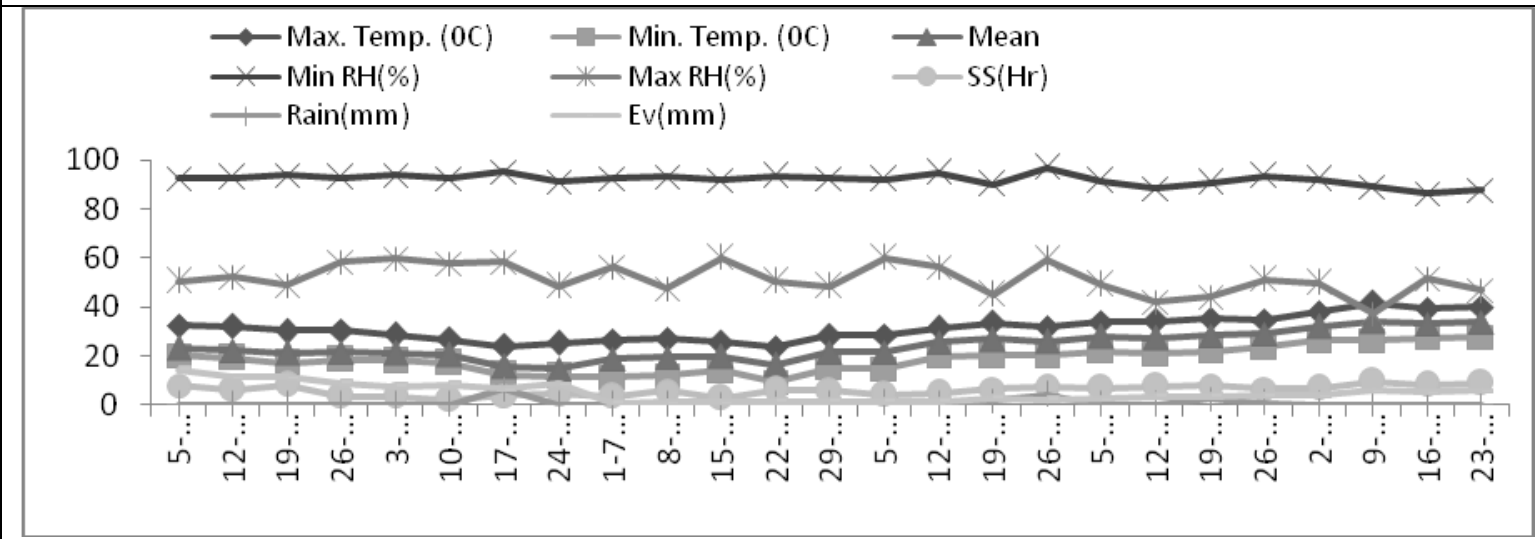

Standard week (2015-2016)

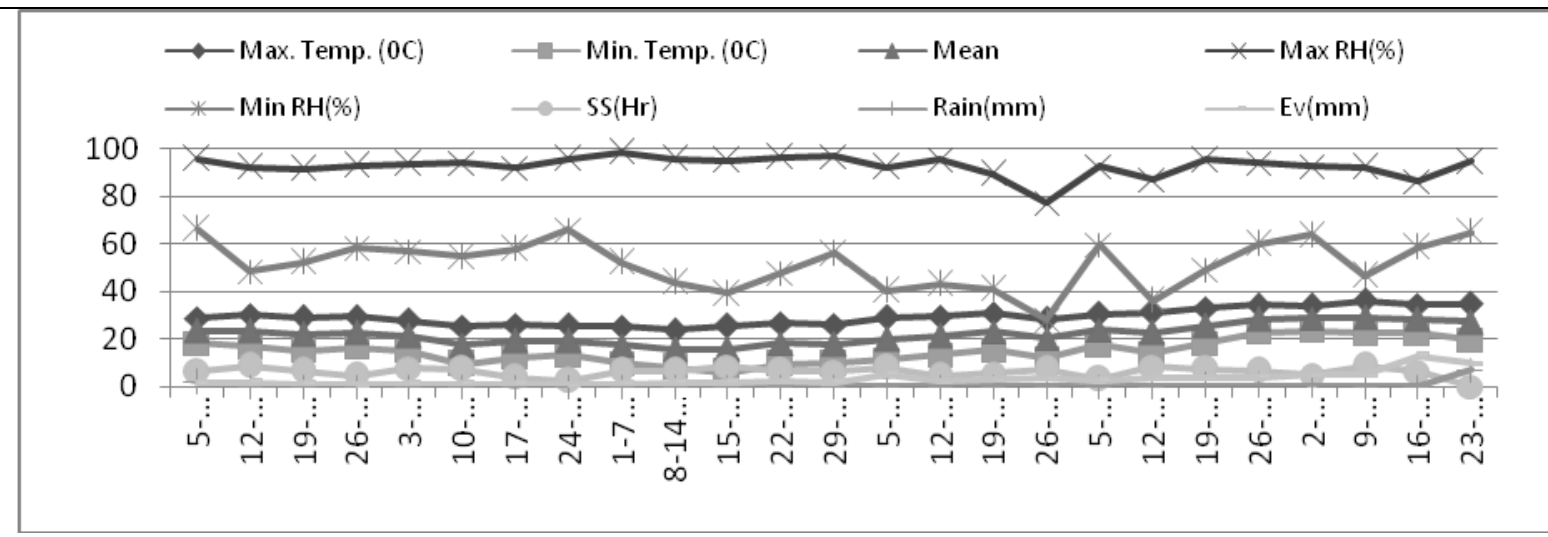

Standard week (2016-2017)

Fig.1 Weekly average temperature, humidity, sun shine hour, rainfall and evaporation during onion season of 2014-15, 2015-16 and 2016-17 

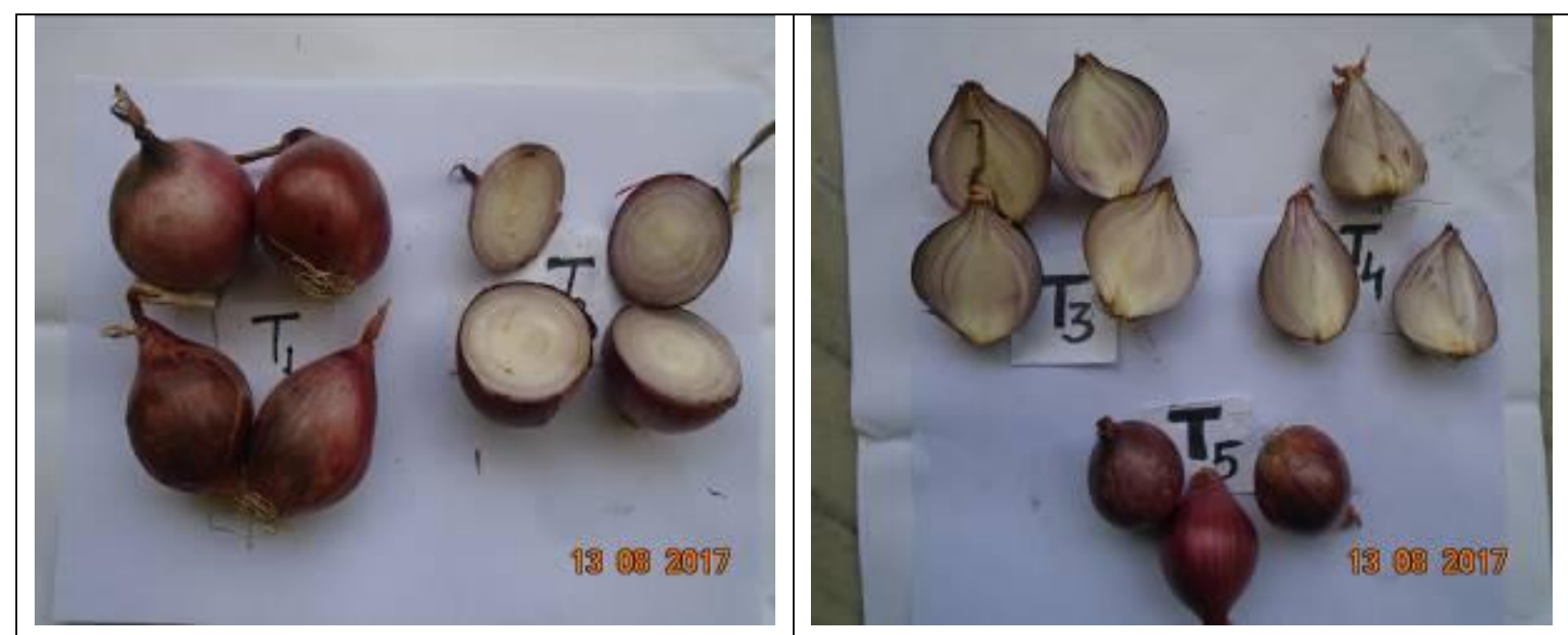

$\mathrm{T}_{1}$ : whole bulb of $70-80 \mathrm{~g} ; \mathrm{T}_{2}$ : cross section cut at middle of 40-50g; $\mathrm{T}_{3}$ : longitudinally half cut of $35-40 \mathrm{~g} ; \mathrm{T}_{4}$ : longitudinally one third cut of $30-35 \mathrm{~g}$ and $\mathrm{T}_{5}$ : small but whole bulb of $30-35 \mathrm{~g}$
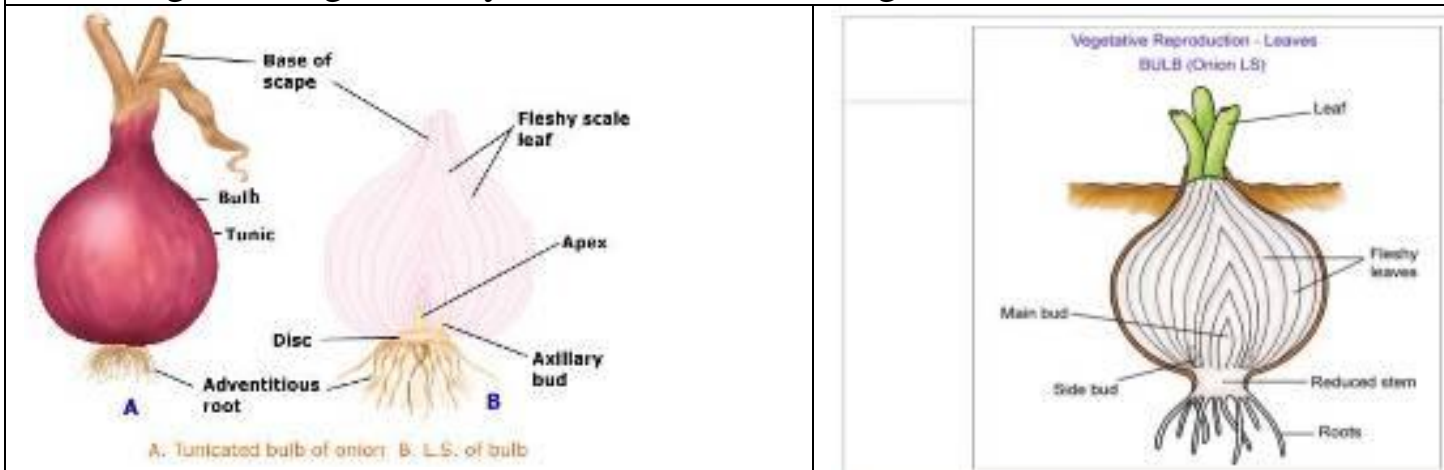

Fig.2 Treatment wise portion and/or size of mother bulb and parts of onion bulb

Table.3 Effect of mother bulb portion on growth and yield components of onion in a field experiment, West Bengal, India (Pooled over 2014-17)

\begin{tabular}{|c|c|c|c|c|c|c|c|}
\hline $\begin{array}{c}\text { Bulb } \\
\text { portion } \\
\text { and size }\end{array}$ & $\begin{array}{c}\text { Spikes } \\
\text { Plant }^{-1}\end{array}$ & $\begin{array}{c}\text { Spike } \\
\text { length } \\
\text { (cm) }\end{array}$ & $\begin{array}{c}\text { Basal } \\
\text { diameter } \\
\text { of Spike } \\
\text { (cm) }\end{array}$ & $\begin{array}{c}\text { Diameter } \\
\text { of the } \\
\text { umbel } \\
(\mathbf{c m})\end{array}$ & $\begin{array}{c}\text { Seeds } \\
\text { umbel }^{-1}\end{array}$ & $\begin{array}{c}\text { Setting } \\
\text { \% }\end{array}$ & $\begin{array}{c}\text { Test } \\
\text { weight } \\
\text { (g) }\end{array}$ \\
\hline $\mathbf{T}_{\mathbf{1}}$ & 4.92 & 93 & 7.69 & 24.61 & 593 & 73 & 3.42 \\
\hline $\mathbf{T}_{\mathbf{2}}$ & 3.77 & 93 & 7.34 & 18.58 & 490 & 68 & 3.31 \\
\hline $\mathbf{T}_{\mathbf{3}}$ & 4.7 & 94 & 7.38 & 21.04 & 578 & 71 & 3.4 \\
\hline $\mathbf{T}_{\mathbf{4}}$ & 2.6 & 88 & 6.14 & 13.75 & 479 & 57 & 2.86 \\
\hline $\mathbf{T}_{\mathbf{5}}$ & 3.11 & 75 & 6.47 & 16.30 & 495 & 54 & 2.81 \\
\hline LSD (0.05) & 0.53 & 11 & 0.86 & 2.23 & 63 & 7.7 & 0.37 \\
\hline
\end{tabular}

$\mathrm{T}_{1}$ : Whole bulb (70-80 g); $\mathrm{T}_{2}$ : Cross section cut at middle (40-50g); $\mathrm{T}_{3}$ : Longitude cut (half) (35-40 g); $\mathrm{T}_{4}$ : Longitude cut (one third) (30-35 g); $\mathrm{T}_{5}$ : Small but whole bulb (30-35 g) 
Table.4 Effect of mother bulb portion on onion seed yield in a field experiment, West Bengal, India

\begin{tabular}{|c|c|c|c|c|}
\hline \multirow{2}{*}{$\begin{array}{c}\text { Mother bulb } \\
\text { portion }\end{array}$} & \multicolumn{4}{|c|}{ Onion seed yield (t ha $\left.\mathbf{~}^{-1}\right)$} \\
\hline $\mathbf{T}_{\mathbf{1}}$ & $2014-2015$ & $2015-2016$ & $2016-2017$ & Pooled \\
\hline $\mathbf{T}_{\mathbf{2}}$ & 0.819 & 0.654 & 0.723 & 0.732 \\
\hline $\mathbf{T}_{\mathbf{3}}$ & 0.472 & 0.387 & 0.443 & 0.434 \\
\hline $\mathbf{T}_{\mathbf{4}}$ & 0.811 & 0.608 & 0.669 & 0.696 \\
\hline $\mathbf{T}_{\mathbf{5}}$ & 0.366 & 0.231 & 0.258 & 0.285 \\
\hline Mean & 0.387 & 0.293 & 0.313 & 0.331 \\
\hline LSD (0.05) (year) & Year & 0.435 & 0.481 & \\
\hline SD (0.05) & 0.038 & Mother bulb portion & Interaction & \\
\hline
\end{tabular}

$\mathrm{T}_{1}$ : Whole bulb (70-80 g); $\mathrm{T}_{2}$ : Cross section cut at middle (40-50g); $\mathrm{T}_{3}$ : Longitude cut (half) (35-40 g); $\mathrm{T}_{4}$ :

Longitude cut (one third) (30-35 g); $\mathrm{T}_{5}$ : Small but whole bulb (30-35 g)

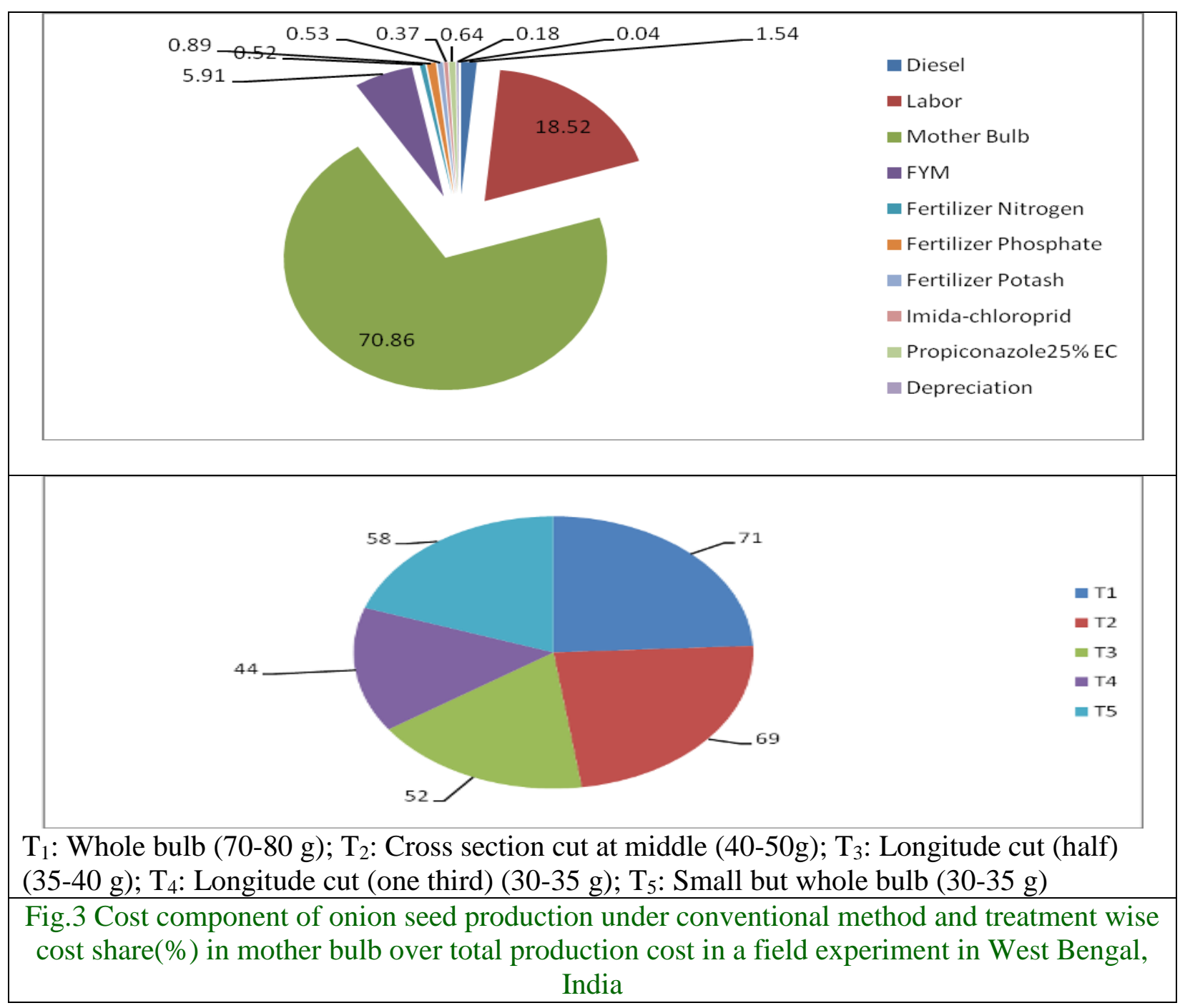


Production cost is higher in $\mathrm{T}_{1}$ (Rs. 338694 $\mathrm{ha}^{-1}$ ) and $\mathrm{T}_{2}$ (Rs. $348894 \mathrm{ha}^{-1}$ ) due to use of bigger size mother bulb. Cost of cultivation was reduced by $32 \%$ in $\mathrm{T}_{3}$ (Rs 231444); by $46 \%$ in $\mathrm{T}_{4}$ (Rs 183794) and by $38 \%$ in $\mathrm{T}_{5}$ (Rs 208494) over conventional $T_{1}$. Gross return directly proportional to seed yield and significantly affected by different bulb size and / or mother bulb. It ranged from Rs. 342000 in $T_{4}$ to Rs 878400 in $T_{1}$. Gross return in $\mathrm{T}_{1}$ and $\mathrm{T}_{3}$ were at par. Net return and BCR were the highest in $\mathrm{T}_{3}$ (Rs $603756 ; 2.61$ ) followed by in $T_{1}$ (Rs 539706; 1.59). Net return was directly related to the price that the producer received for the product and inversely related to the production cost. Both net return and BCR were highest for longitudinal half cut in mother bulb, mainly due to cost reduction but equivalent seed production with conventional system. Among all treatments, economic performance of longitudinal half cut was the best in terms of both net return and BCR (Table 5). In contrast, the lowest BCR was observed for cross sectional half cut $(0.49$ t) should be noted, however, that the average production costs and economic returns shown in Table 2 and Table 5 only illustrate the major differences among treatments. Annual price fluctuations are likely to cause significant variation in the economic performance and also varying economic risk.

In conclusion, there is potential for doubling onion seed production area utilizing the presently available mother bulb. Growth, productivity, production cost and net return generally increased with increasing mother bulb size. However, umbels per plant, seeds per umbel, setting percentage, test weight, seed yield and gross return was at par with using whole bulb of 70-80g and longitudinally half cut of 35-40 g. Cost analysis of onion seed production shows $71 \%$ share alone in procuring mother bulb in farmers' practice. Thus, longitudinally half cut reduced mother bulb requirement by $50 \%$ and production cost significantly reduced than that of using whole bulb. Net return and benefit cost ratio were significantly higher in this half cut tuber than that of using whole mother bulb. This finding can reduce cost of cultivation by $28 \%$ without compromising the seed yield. Considering this remunerative aspect, half cut bulb of 35-40 g weight can be recommended instead of using conventional whole bulb of $70-80 \mathrm{~g}$ weight as cost saving onion seed production options with a possibility of doubling area of seed production with the existing supply of mother bulb. From the above experiment it can be concluded that treatment $\mathrm{T}_{3}$ e.g. longitudinally $1 / 2$ cutted onion bulb (wt 45 $50 \mathrm{~g}$ ) is able to yield almost equivalent quantity of seed $(0.696 \mathrm{~T} / \mathrm{ha})$ with less cost of production as compared with the big whole bulb of 70-80g size and may be suggested as suitable mother bulb with reduced cost to be used for large scale onion seed production program.

\section{References}

Agarwal, A., Gupta, S. and Ahmed, Z. 2010. Effect of bulb size and planting geometry on seed yield and economics of onion (Allium cepa). Indian J Agr Sci 80(4): 333-334.

Ali, M. K., Alam, M. F., Alam, M. N., Islam M. S., and Khandaker, S. M. A. T. 2007. Effect of Nitrogen and Potassium Level on Yield and Quality Seed Production of Onion. Journal of Applied Sciences Research, 3(12): 1889-1899.

Anisuzzaman, M., Ashrafuzzaman, M., Ismail, M. R., Uddin, M. K., Rahim, M. A. 2009. Planting time and mulching effect on onion development and seed production. Afr. J. Biotechnol 8(3): 412416.

Asduzzaman, M. D., Hasan, D., Hasan, M .D. and Moniruzzaman, M. D. 2012. Effect of bulb size and plant spacing on seed 
production of onion (Allium cepa L). Bangladesh J. Agric. Res., 37(3): 405414.

Ashish Ranjan, Mahender Pal and Singh, K. P. 2016. Seed production technique of onion, Rashtriya Krishi | 11 (1) /p 119.

Booker, Jonathon. Steven, Chatfield. Ottoline, Leyser.2003. Auxin acts in xylemassociated or medullary cells to mediate apical dominance. Plant Cell. 15: 495507. Doi: 10.1105/tpc.007542.

Burrows, G. 1989. Developmental Anatomy of Axillary Meristems of Araucaria Cunninghamii. Released from Apical Dominance Following Shoot Apex Decapitation in Vitro and in Vivo. Botanical Gazette, 150:369-377. http://dx.doi.org/10.1086/337782.

De, S., Manna, D., Sankar, A. and Maity, T. K. 2013. Influence of biozyme on growth, yield and quality of onion (Allium cepa L.) cv. Sukhsagar. The Bioscan. 8(4): 1271-1273.

Gomez, K. A. and Gomez, A. A. 1984. Statistical Procedures for Agricultural Research. John Wiley and Sons, New York, 680p.

Singh, H. P., Uma, S., Selvarajan, R. and Karihaloo, J. L. 2011. Micro propagation for Production of Quality Banana Planting Material in Asia Pacific. Asia-Pacific Consortium on Agricultural Biotechnology (APCoAB), New Delhi, India. P. 92.

Hussein, N. 2012. Effects of Nutrient Media Constituents on Growth and Development of Banana (Musa spp.) Shoot Tips Cultured in Vitro. African
Journal of Biotechnology, 11: 90019006.

Khodadadi, M. 2012.The effects of planting date and mother bulb size on quantitative and qualitative seed traits of onion red variety. Int. J Agr. Res Rev 2(4): 324-327.

Khokhar, K. 2014. Flowering and Seed Development in Onion-A Review. Open Access Library Journal, 1, 1-13. doi: 10.4236/oalib.1101049.

Nail, V. R., Patel, P. B. and Patel, B. K. 2014. Study on effect of different organics on yield and quality of organically grown onion. The Bioscan. 9(4): 1499-1503.

Olani Nikus and Fikre Mulugeta. 2010. Onion Seed Production Techniques - A Manual for Extension Agents and Seed Producers, published by (CFAO-CDMDP, 2010, p-3.

Razdan, M. K. 2003. Introduction to Plant Tissue Culture. Science Publishers.

Singh, R. K. and Singh, S.K. 2012. Producing onion seed for rich harvest. Indian Hort. 57: 11-23.

Thimann, K.V. and Skoog, F. 1934. On the inhibition of bud development and other functions of growth substance in Vicia faba. Proceedings of the Royal Society B. 114: 317-339. Doi:10.1098/rspb. 1934.0010.

Woolley, D. J. and Wareing, P. F. 1972. The Interaction between Growth Promoters in Apical Dominance. New phytologist, 71: 781-793. http://dx.doi.org/10.1111/ j.1469-8137.1972.tb01957.x.

\section{How to cite this article:}

Ghosh, D.K., L.K.N. Benukar Biswas, S. Das, C.S. Kartick and Bandyopadhyay, A. 2018. Minimizing Mother Bulb Requirement through Mechanical Option: a Cost Friendly Approach of Onion Seed Production. Int.J.Curr.Microbiol.App.Sci. 7(07): 2646-2655. doi: https://doi.org/10.20546/ijcmas.2018.707.311 